\title{
Når studenter og underviseres forventninger til mediebruk kolliderer
}

Anne Mette Bjørgen, Høgskolen i Innlandet

Yvonne Fritze, Høgskolen i Innlandet

\begin{abstract}
Artikkelen undersøker hvordan bachelorstudenter forholder seg til de mediene og den teknologien det forventes at de bruker i undervisning og i eget studiearbeid. Fokus rettes mot det mange betegner som et gap mellom undervisernes læringsintenderte bruk av medier og studentenes mediepraksiser. Artikkelen baseres på gruppeintervjuer, aktivitetslogger i høgskolens læringsplattform og en spørreundersøkelse. I analysen brukes rammeteori og systemteori for å forstå hvordan studentene fortolker, eller rammer inn, mediepraksiser i undervisning og studiearbeid. Artikkelen bidrar med empirisk basert kunnskap som er viktig for å forstå hvordan individuelle fortolkninger har betydning for engasjement og deltakelse i mediepraksiser. Resultatene synliggjør at det ikke kan tas for gitt at dagens studenter mestrer å bruke medier slik det forventes i høyere utdanning. Vi ser at både studenter og fagpersoner kan bli mer bevisste på hvordan individuelle fortolkninger får betydning for hvordan man engasjerer seg i mediepraksiser, ikke minst i lys av ønsker om studentaktiviserende undervisning.
\end{abstract}

\section{Engelsk abstract}

The article examines how students use and relate to the media and technology that they are expected to use in teaching and in their own study work. The focus is on what many describe as a gap between the teachers 'learning-intensive use of media and the students' media practices. The article is based on group interviews and activity logs in the University College's learning management system, as well as a survey. In the analysis, framework theory and system theory are used to understand how students interpret, or frame, media practices in teaching and study work. The article contributes with empirically based knowledge that is important if we want to understand how individual interpretations have an impact on engagement and participation in digital activities. The results show that it cannot be taken for granted that today's students master the use of technology as expected of them in higher education. The results also show that both students and professionals can benefit from becoming aware of how individual interpretations have an impact on how to engage in various media practices, not least in light of wishes for student activating teaching. 


\section{Innledning}

Digitaliseringen i norsk høyere utdanning bærer med seg krav og forventninger om at faglærere bruker digital teknologi slik at studentene tilbys mer aktiviserende undervisningsformer, noe man forventer vil fremme undervisningskvalitet og bedre læring (Fossland, 2015, s. 11; Krumsvik, 2016, s. 321). I en undersøkelse gjennomført av Norgesuniversitetet[i] argumenteres det for at studentene ønsker mer aktiviserende undervisning med bruk av teknologi de kjenner fra før, men at denne må brukes på andre måter enn hva faglærere nå gjør (Ørnes, Gaard, Refsnes, Kristiansen og Wilhelmsen, 2015).

Gjennom tiår med utprøving av ulike former for digital teknologi i utdanning vet vi imidlertid at det ikke er noen automatikk $i$ at teknologibruk resulterer i aktive studenter, aktiviserende undervisning og bedre læring. Flere forutsetninger må være på plass, som kompetente fagpersoner, pedagogisk tilrettelegging og teknisk støtte. Sist men ikke minst, er det viktig at studentene møter forberedt og deltar aktivt - en forutsetning som ofte viser seg å svikte (Haugsbakk \& Nordkvelle, 2013, s. 113; Haugsbakk, 2010; Moll, Linder \& Nielsen, 2015).

Mange har vært opptatt av hva lærere kan bidra med for å aktivisere studentene gjennom å bruke digital teknologi (Johannessen, Øgrim \& Giæver, 2014; Krumsvik, 2016). Vi opplever imidlertid at studentenes mediebruk ofte er i motstrid med faglæreres forventninger til bruk av medier. Vi ønsker å belyse det mange beskriver som et spenningsforhold mellom hvordan studenter bruker - og ønsker å bruke teknologi i utdanning - og foreleseres teknologibruk (Moll, Linder \& Nielsen, 2015; Selwyn, 2016; 2015). Om vi skal få mer kunnskap om hvordan aktivisere og engasjere studentene, så må vi vite mer om hva de ser som meningsfulle, viktige og relevante digitale praksiser i undervisning og eget studiearbeid (Burnett, 2015, s. 198; Hui, 2018, s. 72). Denne tilnærmingen er sentral for å komme rundt dekontekstualiserte forestillinger om teknologiens fortreffelighet og de unges digitale praksiser og kompetanser (Selwyn, 2016, s. 1007; Adalberon \& Säljö, 2015; Brox, 2017; Gourlay, 2014). Det er for enkelt å anta at alle bruker medier på samme måte, og at de kan det som trenges for å bruke medier i en utdanningskontekst (Tønnessen, 2016).

Som undervisere var vi nysgjerrige på hvordan vår mediebruk samsvarte med studentenes opplevelse av den. Artikkelens overordnede problemstilling er: På hvilken måte opplevde studentene rammesettingen for mediebruken på studieemnet som meningsfull. Artikkelen undersøker følgende delspørsmål:

* Hvilke medietyper brukes i forelesninger og seminarer, og hvordan oppleves dette av studentene?

* Hvilke medietyper bruker studentene i eget studiearbeid, og hvordan oppleves dette?

* Hvordan samsvarer faglærerenes hensikter med mediebruken med studentenes opplevelser?

I analysen benyttes Goffmans (1986) rammeteori samt systemteoretiske perspektiver fra Luhmann (2000) for å analysere hvordan individuelle fortolkninger av rammesettinger for mediebruk skapes og opprettholdes i samspillet mellom studenter, faglærere og undervisningskontekst.

Undersøkelsen tar utgangspunkt i fokusgruppeintervjuer med studenter ved et 15 studiepoengs bacheloremne. Vi har dessuten hatt tilgang til resultater fra en enkel spørreundersøkelse og til informasjon fra aktivitetslogger i studiets læringsplattform. I teksten brukes medie- og teknologibegrepet om hverandre (se f.eks. Fossland, 2015, s. 13ff for en utfyllende drøfting av teknologibegrepet). Vi er mest opptatt av digital teknologi, selv om vi vet at analoge og digitale medier og læringsressurser / medietekster brukes i symbiose med hverandre (Tønnessen, 2016, s. 240). 
Artikkelen bidrar inn i en voksende forskningstrend som er opptatt av de unges egne perspektiver på digitale praksiser (Burnett, 2015; Bjørgen \& Erstad, 2014; Gourlay, 2014, s. 152; Hui, 2018; Lankshear \& Knobel, 2006). Vi mener også at artikkelen bidrar til å nyansere det bildet som tegnes av studenters behov for aktive læringsformer, versus deres behov for effektivisering (Ørnes et al., 2015; Moll et al., 2015).

\section{Forskning på studenters mediebruk}

Flere studier viser at dagens studenter har andre erfaringer og forventninger til teknologibruk enn hva de møter i utdanning (boyd, 2007; Buckingham, 2006; Krumsvik, 2016). Mange peker på at studentene ønsker og forventer at teknologibruken de er kjent med fra fritiden i større grad integreres med akademisk orienterte mediepraksiser, som lesing og skriving av tekst, kildesøk og kritisk kildevurdering (Ørnes et al., 2015, s. 74-75; Adams Becker, Cummins, Davis, Freeman, Hall Giesinger \& Ananthanarayanan, 2017).

I undersøkelsen fra Norgesuniversitetet dokumenteres det at nær alle studenter foretrekker å bruke annen teknologi enn det lærestedet tilbyr når de skal kommunisere eller søke fagstoff (Ørnes et. al., 2015, s. 74-75). Studentene oppgir at de heller tar kontakt med medstudenter via sosiale medier fremfor via lærestedets e-posttjeneste som ligger inkludert i læringssystemet (Tømte \& Olsen, 2013, s. 45). I følge Norgesuniversitetet, bruker studentene oftere Google til å søke fagstoff, framfor å søke via Wikipedia og bibliotekenes fagressurser. Det samme finner Drange og Birkeland (2016) i en omfattende studie av hvordan norske lærerstudenter bruker medier når de studerer (s. 63).

Forskningslitteraturen dokumenterer hvordan Facebook primært brukes til underholdning, og til dyrking av egen identitet og vennskap. Studenter etablerer Facebook-grupper hvor de deler gleder og sorger, og hvor de organiserer kollokviegrupper og hjelper hverandre med oppgaveskriving. Studentene opplever Facebook som et "frirom fra lærere", en privatsfære (Adalberon \& Säljö, 2015; Danbolt \& Birkeland, 2016; Lantz-Andersson, 2016; Moll, Linder \& Nielsen, 2015). En del faglærere bruker Facebook for å få kontakt med studentene, siden de opplever at mange studenter unnlater å bruke lærestedets e-postsystem eller å besøke læringsplattformen (Tømte \& Olsen, 2013). Moll, Linder og Nielsen (2015) argumenterer for at faglærere må lære studenter å se læringspotensialet i online kunnskapsnettverk hvor de har mulighet til å utvide sine faglige perspektiver. Selwyn (2009, s. 173) hevder imidlertid at faglærere bør unngå å innlemme Facebook i undervisningen, og heller la studentene få bygge student-image og utforske studentrollen i fred.

I følge Moll, Linder og Nielsen (2015, s. 10), avslører studentenes mediepraksiser at de er opptatt av raske og effektive, men overflatiske, løsninger på akademiske utfordringer. Tømte og Olsen (2013, s. 42) er inne på noe av det samme når de viser hvordan studentene ofte deler skriftlige arbeider mellom seg, framfor å velge strategier som fremmer reelt samarbeid.

Selwyn (2016) minner om at studenters opplevelser av teknologi som problematisk og forstyrrende bør tas like seriøst som opplevelse av teknologi som positivt og uproblematisk (s. 1016; 2009). En fellesnevner i studiene vi har referert til, er at de understreker spenningsforholdet mellom studentenes vs faglæreres intensjoner med mediebruk. Det er således ikke potensialet ved teknologien i seg selv som er avgjørende for handlingsvalgene. Det er derimot intensjoner, aktiviteter og føringer i kontekstene som bestemmer teknologibruk.

\section{Teoretiske overveielser}

Vi har valgt å kombinere Goffmans og Luhmanns kommunikasjonsteoretiske forståelser. Goffman og Luhmann er begge opptatt av hvordan vi gjennom kommunikasjon skaper og gjenskaper oss selv 
gjennom den kommunikasjonen vi deltar i. I følge Goffman, bærer alle situasjoner i seg rammer, en samhandlingsorden, som hjelper oss å fortolke hvordan vi skal forholde oss til kommunikasjonen. Rammene hjelper oss med å identifisere "what is going on here" (Goffman, 1986, s. 8).

Vi ser Goffmans rammeanalyse som relevant for å forstå hvordan studentene fortolker, eller rammer inn, mediebruk innenfor og utenfor campus - "what seems to count" for dem som meningsfulle digitale aktiviteter (Burnett, 2015, s. 198ff). Rammer skaper felles fokus for hvordan vi skal forholde oss til og fortolke aktiviteter og redskaper som brukes. Vi samhandler, beveger oss og bruker redskaper annerledes i en utdanningssituasjon enn hjemme (Burnett, 2015, s. 200). På campus forventer vi at undervisere og studenter har en felles forståelse av konvensjoner i denne konteksten, og at studentene derfor bruker teknologien i samsvar med våre forventninger. Rammeanalysen hjelper oss å se hvordan studenter ikke alltid handler i tråd med konvensjoner og forventninger, men i høyere grad relaterer innramminger eller opplevelser i en gitt situasjon til tidligere erfaringer (Burnett, 2015). Studentene bringer med seg tidligere erfaringer og kunnskap om teknologi til campus.

Som hos Goffman, finnes det hos Luhmann måter å definere situasjoner eller typer av kommunikasjon på; grunnopptikker og koder. Ethvert sosialsystem har i utgangspunktet en grunnoptikk som man kommuniserer via og som gir kommunikasjonen et fokus, hvorved kompleksiteten kan begrenses og reguleres (Luhmann, 2000, s. 202). Innenfor undervisningens system finnes det også et program eller en konsensus om, hvordan kommunikasjonen skal foregå og ikke foregå (Rasmussen, 2003, s.68). Det er derfor forventet at de kommuniserende forstår hva for eksempel en forelesning innebærer, spesielt når kommunikasjonssituasjonen utfolder seg i et auditorium eller i en forelesningssal, og de interagerende er plassert som de er i forhold til hverandre (Fritze, 2005). Vi forstår så vel forelesninger som seminarer som en intenderte former for kommunikasjon hvis mål er å skape forandring hos studentene (Luhmann, 2000). Når det benyttes forskjellige teknologier og utbredelsesmedier i den tradisjonelle undervisningen i høyere utdanning kan de være med på å utydeliggjøre disse kodene, bl.a. fordi studentene kan ha andre referanser til mediene enn det som er underviserens hensikt. Dette har sammenheng med et annet viktig utgangspunkt her, nemlig at individuelle fortolkninger også rammes inn av, og formidles gjennom teknologien som brukes. Digitale teknologier bidrar til å endre både aktivitetene de blir en del av, og hvordan vi tenker og snakker om de aktuelle aktivitetene; hva vi bør kunne, hva som kan brukes hvordan og i hvilke situasjoner og av hvem (Säljö, 2010). På et overordnet nivå forstås utdanningssystemet som et av samfunnets funksjonssystemer på lik linje med eksempelvis det politiske systemet og det vitenskapelige systemet. Utdanningssystemets funksjon er å skape endring gjennom kommunikasjon/undervisning, og gjenstanden for endringen er den lærende. For å definere og forenkle kommunikasjonen innenfor systemet benyttes koder. Utdanningens kode ses i verdien "å kunne formidle", og deles inn i en negativ og positiv side; formiddelbar/ikke-formiddelbar (Luhmann, 2006, s. 30).

For å skape trygghet og en viss forutsigelighet $\mathrm{i}$ kommunikasjonen kan det derfor være behov for å skape klare referanser til etablerte kommunikasjonskoder (Bolter \& Grusin, 2001). Men det kan også være snakk om en mer korrigerende rammesetting for å skape fokus og opprettholde undervisningens kommunikasjon. Ifølge Luhmann (2000) er det viktig for opprettholdelsen av undervisningssystemet at kommunikasjonen er undervisning og ikke andre former for kommunikasjon. Når det derfor forekommer forstyrrelser og nye systemdannelser må disse vurderes opp mot kommunikasjonens intensjon. Samtidig er det viktig for systemets opprettholdelse at deltakerne gis mulighet til å iaktta hverandres kommunikasjon.

Rammeanalyse hjelper oss å se hvordan ulike aktiviteter med teknologi formidler ulike fortolkningsmåter avhengig av hvilke aktiviteter de er en del av, her innenfor og utenfor rammen av undervisning på campus. Denne tilnærmingen gjør det også mulig å se hvordan studentenes fortolkningsrammer ikke nødvendigvis samsvarer med faglæreres rammer og intensjoner for hva som teller og er viktig i situasjonen (Burnett, 2015, s. 200-201). 


\section{Metode}

Artikkelen bygger på en case-studie av hvordan studenter på et 15 studiepoeng bacheloremne bruker og opplever teknologi i forelesninger og seminarer, samt i eget studiearbeid utenom samlingene. Vi som forelesere var nysgjerrige på om våre forventninger til teknologibruken samsvarte med studentenes. Data er hentet fra intervjuer, aktivitetslogger i læringsplattformen og en enkel spørreundersøkelse. Vårt fokus har vært å belyse det essensielle i studentenes erfaringer ved å fă tak i deres artikulerte opplevelser (Kvale, Brinkmann, Anderssen \& Rygge, 2015, s. 42-44). Derfor er kvalitative data sentrale som kilde.

Vi har foretatt fem fokusgruppeintervjuer (Postholm 2005) med to til fire studenter i hver gruppe. I alt deltok 13 studenter; syv menn og fem kvinner. Alle intervjuer foregikk på utdanningsinstitusjonen i forkant av undervisningen. I intervjuene spurte vi studentene om deres opplevelse av den undervisningsteknologien som er knyttet til studiet, bl.a. læringsplattformen Fronter og vår bruk av medier i forelesninger og på seminarer. Vi spurte også om hvilke medietyper/samarbeidsteknologier som de benytter i eget studiearbeid og hvordan de opplever denne. Det kan være wikier og Google Docs, søketjenester som Wikipedia, Google og biblioteksdatabaser, som Oria og Idunn. Studentene fikk dessuten spørsmål om deres bruk av sosiale medier, siden mange unge er engasjert i dette på tvers av utdannings- og fritidskonteksten; nettsamfunn (Facebook, Messenger) og bilde- og videodelingstjenester som Youtube, Snapchat, Instagram.

Fra læringsplattformen har vi hatt tilgang til en del statistikk om studentenes bruk av de ulike funksjoner i løpet av det semesteret som emnet ble undervist. I denne undersøkelsen har vi sett på i hvilken grad studentene har benyttet informasjonen som ble lagt ut, og på hvilket tidspunkt de brukte den, før eller etter samlinger. Vi har ikke identifisert enkeltindividers trafikk på læringsplattformen, men har fulgt den samlede gruppes trafikk.

Den Kahoot-baserte spørreundersøkelsen ble utarbeidet i forbindelse med en forelesning om sosiale medier, hvor vi bl.a. spurte studentene om deres bruk av sosiale medier hjemme og under forelesninger og faglige seminarer. Det var 82 studenter på dette bacheloremnet, mens det på forelesningen hvor spørreundersøkelsen ble utført deltok 61 studenter, eller omkring 75 prosent av alle studenter på emnet. Av de 61 studenter som var på forelesningen deltok 59 i spørreundersøkelsen, hvilket vil si omkring 72 prosent av alle studenter. Heller ikke i spørreundersøkelsen kunne enkeltindivider identifiseres.

Som en del av et forventet læringsutbytte i emnet Mediepedagogikk, skal studentene reflektere over egne erfaringer med mediebruk, herunder erfaringer fra bruk av læringsplattform og fra studiearbeid ellers. Vi oppfordret dem også til å utdype sine erfaringer med akademisk mediebruk i forelesninger og på seminarer, spesielt knyttet til bruken av videoklipp. Det ble tidlig i semesteret informert om at vi sideløpende med undervisningen ville vi forske på studentenes mediebruk, så vel gjennom intervjuer, som gjennom deres spor i læringsplattformen og fra deres svar i Kahoot-undersøkelse. Studien er gjennomført i samsvar med de etiske retningslinjene til Norsk senter for forskningsdata (NSD).

Siden dette er en relativ liten studie har den visse begrensninger i forhold til resultatenes generaliserbarhet. Samtidig understreker Tjora (2017) at forskeren i hovedsak må tenke på om utvalget er relevant og kan gi svar på de forskningsspørsmålene som stilles, og ikke først og fremst hvor mange intervjuer som er med i undersøkelsen. Vi mener at vårt utvalg var tilfredsstillende for å få svar som gir mening for vår problemstilling og som kan diskuteres i forhold til en teori. Begge forfatterne var faglig og administrativt ansvarlige under datainnsamlingen, noe som kan ha hatt positiv effekt på rekrutteringen av informanter, på utviklingen av forskningsdesign samt på intervju og tolkningsarbeid. Man skal imidlertid ikke se bort fra at det også kan ha farget studentenes svar og våre tolkninger. 


\section{Presentasjon av resultater}

\section{Undervisernes forventninger til bruk av medier}

På dette bacheloremnet ble en rekke medier benyttet i tilknytning til undervisningen. Først og fremst ble læringsplattformen Fronter brukt for å distribuere praktisk informasjon til studentene om undervisning, pensum, arbeidskrav og eksamen. Det ble lagt ut læringsmateriell i forkant og etterkant av forelesninger og seminarer, og studentene leverte inn og fikk tilbakemelding på arbeidskrav via læringsplattformen. Det var forventet at studentene holdt seg oppdaterte på informasjonen som ble lagt ut her.

Videre benyttet studentene mobiltelefon, nettbrett og/eller PC til notatskriving, i forbindelse med produksjon av arbeidskravet digital fortelling, som avspiller ved analyse av tv-programmer, og som dokumentasjonsredskap (video og kamera) under museumsbesøk. Dessuten ble mobiltelefonen benyttet løpende til besvarelse av enkle quiz og spørreundersøkelser i Kahoot, hvor vi typisk testet studentenes holdninger til medier og spurte om deres egen mediebruk.

Under forelesninger og på faglige seminarer benyttet underviserne ofte YouTube-videoer eller annet audiovisuelt materiale for at eksemplifiserer lærestoffet og som bakgrunn for diskusjoner. Også "meningsmålinger" via Kahoot ble brukt som bakgrunn for diskusjoner. Læringsplattformen ble ofte åpnet under forelesningene for å vise hvilket undervisningsmateriale som var lagt ut og hvor på sidene det kunne finnes. Dessuten viste vi sider med praktisk innhold ved f.eks. gjennomgang av arbeidskrav og eksamen. Vi har hatt en del forsøk med frivillig kontra obligatorisk deltakelse på forelesninger og seminarer. Mens denne undersøkelsen foregikk var det obligatorisk møteplikt på emnet.

En del av studiets målsetting var å skape bevissthet hos studentene om egen mediebruk. Vi mente derfor også at deltakelse i denne undersøkelsen ville kunne bidra til dette.

\section{Studentenes bruk av medier under forelesninger og seminarer}

I intervjuene spurte vi studentene om og eventuelt til hvilket formål de bruker mobiltelefon, nettbrett og PC under forelesninger og seminarer. I det semesteret som undersøkelsen foregikk, hadde vi igangsatt et forsøk, hvor studentene prøvde å skifte fra elektronisk notering til bruk av penn og papir. Det var derfor ikke overraskende at flertallet sa at de benyttet penn og papir til notering, mens bare få fortsatt benyttet nettbrett og PC til å ta notater. Alle sa at de benyttet mobiltelefonen i forbindelse med Kahoot-undersøkelser. Flere av studentene sa imidlertid også at de selv og andre studenter benytter mobiltelefon, PC og nettbrett til utenomfaglig aktivitet. De sa videre at den utenomfaglige aktiviteten i hovedsak handler om å se på YouTube-videoer og tv, eller å kommunisere via sosiale medier.

Siden vi ofte viser videoklipp i forelesninger, gjerne fra Youtube, med intensjon om å skape engasjement og variasjon, spurte vi studentene hvordan de opplevde denne praksisen. De fortalte at video kunne virke engasjerende, men også forstyrrende. Det siste var tilfellet når vi forelesere rotet for mye med det tekniske, skiftet mellom filmer eller slog av og på lyset. Studentene beskrev slike episoder som "brudd", de mistet fokus og "koblet seg av". En kvinnelig student sa følgende om tekniske problemer under forelesninger og seminarer: «[...] det med tekniske problemer, det kan jo ikke dere noe for, det er ikke deres skyld. Men jeg faller veldig fort ut hvis det blir mye tull med lyden» (Anja).

Noen fortalte også at det å se på video ble opplevd mer som avslapning enn som undervisning, men at video likevel kunne bidra til å forstå budskapet. En mannlig student forklarte hvordan han fikk et annet fokus når han så video: 
[...] så er det jo hva man assosierer med Youtube da. Når man ser på film sånn generelt så slapper man mere av. Budskapet for meg kommer ganske lett inn når det er i filmformat, av en eller annen grunn [...]det er litt sånn rart, det kan være det som en er mest vant med. Jeg har jo sittet mer på youtube enn i forelesning. Man gjør jo det man er vant til. (Bjørn).

En kvinnelig student opplevde video som avslappende, fordi hun med video ikke trengte å late som om hun fulgte med på hva foreleserne snakket om: «[...] ellers syns jeg det har vært ganske godt å få koblet av litt, da føler jeg at jeg ikke må anstrenge meg så mye[...] kort og enkelt er jo mye bedre å følge med på enn en utdypende person [fagperson]» (Cecilie).

Ved spørsmål om hva de syns om at vi prøver å eksemplifiserer teoretiske poenger i forelesninger og på seminarer med videoklipp, svarer flere studenter at de fram for de mer teoretiske forelesninger med eksempler foretrekker mer pensumrelaterte forelesninger og konkrete anvisninger på hvordan de skal forstå pensum. En mannlig student sier følgende om å få konkrete leseanvisninger:

[...] Jeg savner litt mer det mer konkrete teoretiske, «detstår i den boka og det står i den boka» [...] da får du mer pekepinner [...] Fra mitt ståsted nå, er jeg veldig usikker på hvilken av de tre bøkene jeg skal bruke. Hvem er liksom Alfa, hvem er Bravo og hvem er Charlie? For å si det på den måten da (Dan).

Erika, en kvinnelig student sier seg enig og følger opp Dans beskrivelse: «[...] ja, litt sånn, her er grunnmuren i hvor det står om det. Og litt sånn, det her er bibelen. Hvilken er bibelen?, hvilken er den aller viktigste?» Erika uttrykker her ønsker om tydeligere leseveiledning som forteller hva som er viktigste pensumlitteratur.

Når vi spør disse studentene om det ikke er tilstrekkelig med de leselistene som er laget til hver forelesning, svarer den kvinnelige studenten følgende:

[...] men vi er ikke flinke nok til å faktisk gidde å se på den. Det tror jeg kan være greit å smekke inn i powerpointene. At her står det om det i kompendiet for eksempel, eller at det står i den boka. Da burde det jo ikke være så vanskelig å plukke opp den boka for eksempel (Erika).

\section{Utenomfaglige aktiviteter under forelesninger og seminarer}

Fra en enkel Kahoot-spørreundersøkelse får vi et bilde av hvor mange studenter som benyttet medier under forelesninger og seminarer til utenomfaglige aktiviteter, og dermed ikke fulgte våre anvisninger for mediebruk. Da vi spurte hvor ofte de besøkte sosiale medier under forelesninger og seminarer, svarte 72 prosent av studentene at de besøkte sosiale medier under alle forelesninger og seminarer, mens 12 prosent bare besøkte dem et par ganger om uken. Ni prosent av studentene sa at de sjeldent går på sosiale medier under forelesninger og seminarer, mens syv prosent aldri gjorde det. Når vi spurte de samme studentene om, hvor mange av deres medstudenter som benyttet sosiale medier under forelesninger og seminarer var tallet noe høyere. 


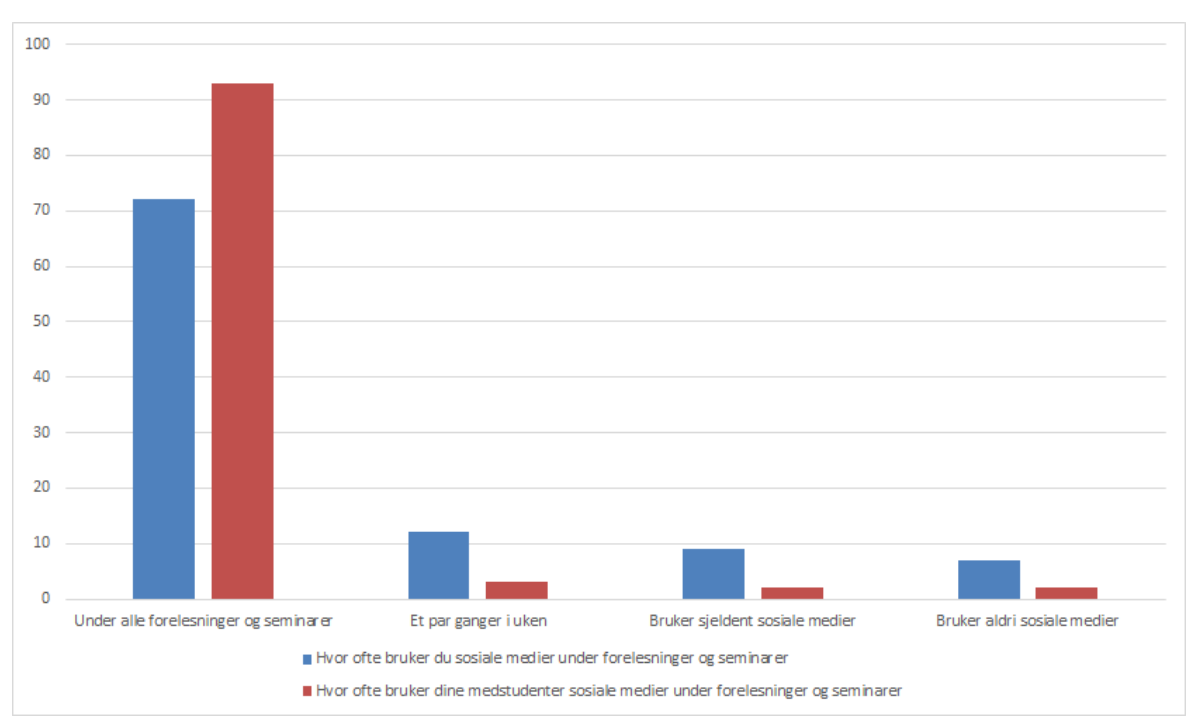

Figur 1. Studentenes bruk av sosiale medier under forelesninger og seminarer

Som man ser av figuren sa hele 93 prosent av studentene at de andre benyttet sosiale medier under alle forelesninger og seminarer, mens tre prosent sa at de andre benyttet dem et par ganger om uken. To prosent sa de andre sjeldent benyttet sosiale medier i undervisningen og to prosent sa at de andre aldri benyttet dem.

\section{Bruk av læringsplattform}

Dette bacheloremnet er organisert i syv tematiske moduler eller samlinger. Gjennom læringsplattformen mottar studentene informasjon om undervisningsplanen og eventuelle endringer i denne. Det legges også ut læringsmateriell, foreleserens Powerpoint-plansjer samt lenker til relevante nettsider (artikler, diskusjoner, video mm.). På læringsplattformen får studentene dessuten tilgang til informasjon om eksamen, kompendium med leseveiledning, oversikt over arbeidskrav og resymer fra artikler.

Fra læringsplattformens statistikk kunne vi få en viss oversikt over studentenes bruk av læringsmateriell og på hvilket tidspunkt de hadde brukt det. Vi så bl.a. at det langt fra var alle studenter, 38 prosent, som så på undervisningsmateriellet før de kom på samlingene. Statistikken viste videre at det bare var 42 av de i alt 83 studenter som hadde besøkt alle syv sider/samlinger. Omkring 10 prosent av studentene var inne på læringsplattformen for første gang rett før innlevering av eksamensmappen.

Som en del av seminararbeidet utarbeider studentene resymeer av pensumlitteraturen, som legges ut i læringsplattformen. På dette kullet var det er liten interesse for resymeene, og under 10 prosent av studentene besøkte disse sidene. Det var på daværende tidspunkt mappeeksamen på emnet, og arbeidskrav kunne forbedres før de ble lagt i mappen. Mens få studenter var interesserte i å lese de andres litteraturresymeer, så vi at alle 83 studenter leste tilbakemeldingene fra underviserne på eget arbeidskrav.

\section{Studentenes mediebruk i studiearbeidet}

\section{Sosiale medier som hjelp og støtte}

Vi spurte studentene hvem de først henvendte seg til for å få hjelp om de strever med noe faglig. De fortalte at de brukte å henvende seg til medstudenter i kollokviegrupper eller venner. De fleste foretrakk å møtes ansikt-til-ansikt, men om dette ikke var mulig så snakket de sammen via Facebook, Messenger 
eller Snapchat. Facebook ble i tillegg brukt til å organisere kollokvier: «Jeg bruker Face mest til å organisere gruppen, ikke til diskusjoner» (Finn).

Utover å kunne brukes som ressurs for organisering av studiearbeid, uttrykte flere tvil knyttet til spørsmål om Facebook kunne brukes til noe faglig fornuftig. Flere betegnet Facebook som noe privat: «Facebook og Messenger er egentlig mitt private liv» (Finn).

Alle understreket at de velger mer formelle kanaler, som e-post, om de skal kontakte fagpersoner: «[...] det er liksom noe med den foreleser/veileder, da vil jeg ha det på mail» (Gunn).

Studentenes e-postadresser ligger i høgskolens læringsplattform. De fortalte at de sjelden var innom der. To grupper mente vi faglærere burde opprette en egen Facegruppe for studentene, siden så få brukte fronter.

\title{
Samarbeid via nettet
}

Studentene uttalte at de foretrakk å samarbeide i samme fysiske rom. Men måtte de samskrive på nett oppga noen at de foretrakk Word, men majoriteten brukte Google Docs. Mange mente imidlertid at Google Docs var tungvint fordi sidene "hopper" mens de skriver, noe som også gjør det vanskelig å ha oversikt over endringer. En kvinnelig student forklarte hvordan gruppen håndterte slike utfordringer ved å kombinere Google Docs med Messenger:

\begin{abstract}
Vi har liksom en kryss tvers-greie der, da er det veldig greit å si ifra på Messenger «du jeg har endra på det, kan du ta en titt på det» og sånn [...] For da veit vi om det, i stedet for å gå og sjekke om det har blitt noen endringer på det dokumentet, så kan man gå rett til avsnittet. Og så bare smokker du inn i word-dokumentet da (Heidi).
\end{abstract}

Studenten beskriver her hvordan de kombinerer to teknologier for å få bedre oversikt over tekstene de sender hverandre. Det kom også fram at de pleide å dele gruppearbeidet mellom seg med en oppnevnt ansvarlig redaktør. Rett før innlevering møttes gruppene for å ferdigstille oppgaven. Mange fortalte at de opplevde nettbasert samarbeid som utfordrende og tidkrevende. I uttalelsen under forklarer en mannlig student hvorfor skriftlig kommunikasjon kan være utfordrende: «For meg er ikke det aktuelt som samarbeidskommunikasjon. Jeg er mye mer interessert i at vi skal møtes på skolen [...] så tar det mye lenger tid enn det det burde tatt» (Dan).

Studenten nevner her det å formulere seg skriftlig som utfordrende, og han trekker igjen fram et poeng studentene tidligere har nevnt, nemlig at det er mer interessant å møtes ansikt-til-ansikt.

\section{Relevante nettressurser}

På spørsmål om hva som ble opplevd som relevante nettressurser, fortalte flere at Google og Wikipedia var velegnet for "en første overblikk over ting", for eksempel et tema eller fagbegreper. Slike uttalelser ble fulgt opp av utsagn om at det er viktig å ikke stole på alt i Wikipedia. I tillegg til Google og Wikipedia ble flere nettsider nevnt: Store norske leksikon, Utdanningsdirektoratet, Kunnskapsdepartementet og Oria på høgskolens bibliotek. De logget seg bare inn på læringsplattformen sporadisk, mest når de ble minnet om det. Noen kom også inn på betydningen av å være kritisk, i form av å sammenligne det som ble skrevet på Facebook med det som står i pensumbøker. 


\section{Diskusjon}

\section{En studentmasse utenfor kommunikativ rekkevidde?}

Vår spørreundersøkelse viste at 72 prosent av studentene besøker sosiale medier under alle forelesninger og seminarer, mens hele 93 prosent opplever at de andre studentene gjør det. Tallene kan tyde på at utenomfaglig mediebruk ikke bare skaper frakobling for mediebrukeren selv, men det skaper også forstyrrelser for de andre studentene. Når studentene velger sosiale medier eller f.eks. ser på video mens underviseren foreleser eller leder et seminar, kobler de seg fra undervisningens kommunikasjon og trer inn et 'privat' kommunikasjonssystem (Fritze \& Nordkvelle, 2017). Om utdanningens funksjon er å skape endring gjennom formidling (Luhmann, 2006) må det være mulig for undervisere og lærere å kommunisere. Med mindre man tror på multitasking ser det ut til at tre fjerdedeler av våre studenter på dette emnet er utenfor kommunikasjonens rekkevidde i kortere eller lengre perioder av undervisningen. Muligheten for å observere hverandres "face" eller kommunikative handlinger, så vel muntlige som kropsspråklige, oppfattes hos Luhmann (2000) som essensielt for å oppnå forståelse og dermed for opprettholdelse av kommunikasjonssystemet.

Materialet viser hvordan studenter i høy grad kobler seg fra undervisningens kommunikasjon gjennom f.eks. sosiale medier, hvilket gjør det vanskelig for underviseren og studentene å observere hverandres forståelse av undervisningen. Dermed mister de kommuniserende også muligheten for en kollektiv forståelseskorrigering, og for underviseren vil det bli vanskelig å tilpasse seg studentenes behov. I beste fall kan undervisningen fremstå som en monolog, mens studentene "skjerming" mot undervisningens kommunikasjon i verste fall kan gjøre temaet ikke-formiddelbart (Luhmann, 2006, s. 30).

Studentenes frakobling kan også tolkes av andre studenter som et tegn på at underviseren og/eller innholdet er uinteressant, og dermed skape en negativ kollektiv forståelse av undervisningen (Goffman, 1986; Luhmann, 2000). Om underviseren ser avkoblingen på samme måte, kan han/hun forsøke å oppnå kontakt med studentene ved å kommunisere tydeligere, gi eksempler eller skape diskusjon. Underviseren kan også prøve å ta kontakt direkte til den eller de som kobler seg ut, og eventuelt korrigere kommunikasjonen gjennom forbud og restriksjoner.

Man skal imidlertid ikke se bort fra at det i studentenes avkobling ligger en viktig "beskjed" til oss om mer strukturelle problemer i høyere utdanning, hvor tradisjonelle undervisningsformer og krav om deltakelse på alle forelesninger og seminarer forsøkes overført til den moderne studentens hverdag og studievaner. Mange av våre studenter har hel- eller deltidsjobb ved siden av studiene. Den massive avkoblingen fra undervisningen kan derfor også ses som et uttrykk for at studentene utelukkende stiller opp for å bli registrert i vårt system, mens de egentlig er et helt annet sted. Møteplikt til forelesninger og seminarer kan være en forstyrrelse for studentene på et mer strukturelt plan, og det kan diskuteres om ikke endringer av undervisning og studentatferd også er et spørsmål om forhandling av rammer (Krumsvik, 2016).

\section{Undervisernes teknologibruk skaper forstyrrelser og avkoblinger}

På dette bacheloremnet benyttes en del eksempler, f.eks. videoklipp fra YouTube eller Kahoot-quiz og spørreundersøkelser, fordi underviserne har tro på at variasjon og redundans i undervisningen kan øke læringsmulighetene. Vi ser imidlertid at studentene avkobler seg undervisningens kommunikasjon når det oppstår tekniske problemer, og det gjør det dessverre ofte når vi benytter teknologi. Vår mediebruk har dermed ikke bare positive pedagogiske effekter, men de tekniske problemene den medfører kan skape uforutsette og negative effekter for studentenes læringsmuligheter. Våre funn støttes av studien til Selwyn (2016), som finner at studentene assosierer slike forstyrrelser med tap av verdifull tid og opplevelse av at det er fånyttes å møte på forelesninger: «Students saw these disruptions as 'lost precious 
time' (1920), 'a hindrance to productivity' (932), and contributing to a sense of there being 'no point in attending lectures' (858)” (Selwyn, 2016, s. 1012).

\section{Fra produsenter til konsumenter}

En annen og kanskje mer overraskende tilbakemelding fra studentene er deres ønske om mere pensumrelaterte forelesninger. De foretrekker forelesninger med mere konkrete henvisninger til pensum, enn forelesninger som legger opp til at studentene sammen reflekterer over teorien, for eksempel gjennom bruk av videoeksempler/-case. I likhet med studien til Moll, Linder \& Nielsens (2015), som viste at studenter ofte søker raske og effektive løsninger, ser vi ønsket om pensumrelaterte forelesninger som et behov for å effektivisere studiearbeidet. Sett i et kommunikasjonsperspektiv, kan studentenes ønsker også framstå som at de foretrekker å være konsumenter av undervisning, fram for aktive innholdsprodusenter gjennom en dialogisk undervisningsform. Drange og Birkeland (2016) viste til lignende atferd da de undersøkte lærerstudenters bruk av sosiale medier, mens Norgesuniversitetets undersøkelse (Ørnes et.al, 2015) viste at studenter ønsker mer studentaktiviserende undervisning.

På ett område responderer studentene imidlertid helt i tråd med våre forventninger til deres mediebruk. De leser stort sett alltid våre tilbakemeldinger på deres skriftlige arbeidskrav i læringsplattformen. Dette bekrefter igjen vår oppfattelse av at studentene er opptatt av å effektivisere, og at studiearbeid som er direkte eksamensrelatert ofte får førsteprioritet (Moll et.al, 2015). Når eksamen på dette emnet er mappeeksamen, med mulighet for å forbedre arbeidskravene, er det naturlig at våre tilbakemeldinger alltid leses. Studentenes ønske om å få lagt ut undervisningsmateriell på læringsplattformen i forkant av forelesninger og seminarer, sammen med deres sparsomme bruk av disse, kan leses inn i samme effektiviseringsmønster, hvor eksamen innhenter studentene og derfor velges bare det aller mest nødvendige.

\section{Sosiale medier som motsvar til utfordrende institusjonelle Iøsninger?}

En fellesnevner i vårt materiale er beskrivelser som viser hvordan sosiale medier rammes inn som mer relevante og foretrukne studieverktøy, på bekostning av høgskolens løsninger (Tømte \& Olsen, 2013). Det er særlig høgskolens læringsplattform Fronter som oppleves som tungvint og vanskelig, noe studentene begrunnet med at de måtte "klikke og klikke" seg fram til informasjon. Vi finner samme tendenser i studien til Drange og Birkeland (2016, s. 61). Studentene oppga også at de kjente på forventninger fra faglærere om å besøke læringsplattformen, noe som førte til at de gjorde det innimellom.

Materialet viser at Facebook og Messenger oppleves som relevante ressurser for å dele studierelatert informasjon og administrere kollokviegrupper. Studentenes beskrivelser viser hvordan de benytter og overfører fortolkninger og mediepraksiser knyttet til bruk av sosiale medier i fritiden inn i studiearbeidet. Våre funn er i tråd med studier som viser at studenter opplever Facebook som noe privat som brukes til underholdning, og eventuelt til ikke-faglig kommunikasjon i studiearbeid (Adalberon \& Säljö, 2015; Lantz-Andersson, 2016; Moll, Linder \& Nielsen, 2015; Selwyn, 2009). Våre resultater finner imidlertid ikke støtte i argumentasjonen fra Norgesuniversitetet, som hevder av studenter ønsker at lærestedene i større grad bruker medier de er kjent med fra fritiden til studentaktiviserende undervisning (Ørnes et al., 2015). Dette kan ha med at vi i begrenset grad integrerer sosiale medier i undervisningen, og følgelig at våre studenter ikke er vant til dette. Om vi skulle velge å bruke for eksempel Facebook, vil det kreve en annen didaktisk tilnærming. Vi kunne også fulgt oppfordringen fra Moll, Linder og Nielsen (2015), om å oppmuntre studentene til å se potensialet i faggrupper på nettet. Dette vil imidlertid betinge at vi bruker dette mer aktivt og tydelig i undervisningen. 
Materialet inneholder flere eksempler hvor studentenes beskriver Messenger og Facebook som relevante ressurser for informasjonsutveksling og samarbeid vitner om at de ser det som viktig å bruke studietiden effektivt (Moll et al., 2015; Tømte \& Olsen, 2013). Slike orienteringer kan imidlertid åpne for å søke det Moll med kolleger kaller raske og overflatiske løsninger på akademiske utfordringer. Flere eksempler i vårt materiale illustrerer tydelig at studentene forholder seg til informasjonssøk, kildevurdering og samarbeid med en instrumentell innramming. Studentene beskriver hvordan de søker hjelp på måter de kjenner fra før, det vil si i nærmeste vennekrets på Facebook, eller hos medstudenter på campus eller via sosiale medier. De benytter nærmere bestemt kjente strategier ved at de kontakter sitt eksisterende sosiale nettverk på Facebook (Moll et al., 2015; Selwyn, 2009). Det er rimelig å hevde at de opplever den samhandlingsorden som gjelder på Facebook som kjent og trygg. Det samme kan sies om måten de rammer inn aktiviteten å samskrive på nett. De beskrev hvordan de effektivt delte arbeidet mellom seg, ut fra formelen "du gjør det, så gjør jeg det", altså som noe de var vant med fra tiden før nettbasert samarbeid. Studien til Tømte og Olsen peker på et lignende fenomen (2013, s. 42).

Eksemplene presentert over viser hvordan studentene opplevde flere av høgskolens ressurser som vanskelige å bruke. De opplevde høgskolebiblioteket som vanskelig å navigere i, og de søkte heller etter fagressurser og begrepsforklaringer på nettet, i Google, Wikipedia eller i Store Norske nettleksikon (Se også Tønnessen, 2016). Slike strategier kan beskrives som minste motstands vei. Som i studien til Moll et al. (2015, s. 13), var det ingen av våre studenter som beskrev noen spesielt sofistikerte former for bruk av nettfora eller databaser. Det skal understrekes at selv om studentene ser ut til å være opptatt av effektive strategier, så blir det likevel for enkelt å hevde at dette automatisk fører til overflatiske løsninger på akademiske utfordringer. Det er ikke gitt at studentene egentlig ønsker det slik. Det er mye mulig at rammefaktorer, som forpliktelser overfor familie og jobb, tvinger fram effektive strategier, men dette tilhører en annen diskusjon.

Det er mye i materialet som tyder på at studentene fortolker gjengse akademiske fagressurser, som læringsplattformen Fronter og bibliotekets databaser, som vanskelige, endog overflødige. Studentene ser ut til å klare seg i studiehverdagen med sosiale medier og Google. På den ene siden kan vi hevde at studentene viser begrensede kompetanser på bruk av akademiske databaser, søkestrategier og kildevurdering - kompetanser vi tar for gitt at de bør ha i en studiehverdag. På den andre siden kan vi si at studentene demonstrerer andre typer kompetanser knyttet til å bruke sosiale medier som gjør at de overlever en kompleks hverdag der de må turnere studier med jobb og andre forpliktelser. For eksempel demonstrerer de handlekraftige valg og strategier i sine beskrivelser av hvordan de kombinerte Google Docs med Messenger for å samskrive raskere, mer oversiktlig og mindre trøblete.

Mens faglærere forventer økt engasjement i det en Youtube-video startes, viser flere eksempler hvordan studentene beskriver at de sitter rolig og ikke trenger å late som de følger med. Dette vitner imidlertid om at de kjenner godt til rammene for en forelesning, hva som forventes av dem og hva som er viktig. Studentene sier seg også flere ganger enige i hverandres fortolkninger av situasjonen, noe som understøtter vårt inntrykk av deres kjennskap til rammesettingen. Slike beskrivelser, sammen med beskrivelser av hvordan de opplever frakopling og rytmebrudd når faglærere plundrer med det tekniske, kan tolkes som forhandlinger om rammer. Det samme kan sies om studentenes uttalelser om at de ønsker effektiv tidsbruk, både i eget studiearbeid, i undervisningen og ved tilrettelegging av fagressurser.

\section{Konklusjon}

I vår undersøkelse har vi hatt fokus på hvordan studenter bruker medier i undervisningen og i eget studiearbeid, og hvorvidt denne bruken samsvarer med faglærernes hensikter med mediebruken. Som mange andre studier, viser også denne studien at det er spenninger og gap mellom hvordan studenter og forelesere bruker medier, og hva studentene opplever som relevant og verdifullt $i$ en studiesetting. Studentene drar med seg forventninger, erfaringer og kompetanser mellom campus og fritid, og disse 
samsvarer ikke nødvendigvis med faglæreres intensjoner (Adalberon \& Säljö, 2015; Burnett, 2015; Moll, Linder \& Nielsen, 2015). Studentene forholder seg kun i begrenset grad til høgskolens analoge og digitale fagressurser og læringsplattform. Gode intensjoner om å stimulere til læring gjennom bruk av teknologi i tilknytning til undervisningen kan av studentene oppleves som forstyrrende eller unødvendig. Omvendt, ser vi at studentenes teknologibruk under forelesninger og seminarer kobler dem av undervisningen og skaper forstyrrelser for underviser og andre studenter (Selwyn, 2016, s. 1012).

Eksemplene som er presentert og drøftet viser hvordan mediepraksiser, som bruk av Youtube, kan rammes inn på ulike måter. For studentene kommer fritidsrammen i forgrunnen, og denne samsvarer ikke helt med læreres intensjoner omkring bruk av Youtube for undervisningsformål. Vår måte å tolke materialet på er i tråd med Burnetts (2015, s. 200) understreking av hvordan rammeteori kan åpne for å se hvordan vi skaper mening ut av å delta i digitale praksiser - her hvordan studentenes fortolkninger ikke alltid samsvarer med forelesernes fortolkninger. Denne tilnærmingen dreier oppmerksomhet mot det komplekse samspillet mellom studenter og lærere, intensjoner, aktiviteter med og uten teknologi, fagressurser og den helhetlige akademiske konteksten.

Funnene i denne studien indikerer også at studentene prøver å forhandle om hva som er akseptable rammer for mediebruk i forelesninger og eget studiearbeid. De har gitt tilbakemelding på hva de mener er utfordrende ved lærestedets teknologiske løsninger, spesielt knyttet til informasjonssøk på læringsplattformen og i akademiske databaser. Studentene har innspill til bruk av video i forelesninger, og de beskriver hvordan de balanserer studiearbeid versus andre forpliktelser. I sum kan dette leses som innspill i forhandlinger om hvordan vi kan forstå en moderne studentrolle. Studentene må ofte jobbe hel- eller deltid, og har ikke tiden som regnes som normert tid til studier. Vi kan heller ikke ta for gitt at de mestrer det som kreves i en akademisk setting.

Det er stadig et åpent spørsmål hvordan lærestedene best kan tilrettelegge for heltids- og deltidsstudier. Det er sentralt at faglærere og tilretteleggere av undervisning har innsikt i fortolkningsrammene som studentene bringer med seg inn i auditorier og lesesaler. Krumsvik (2016) understreker at ansvaret for å skape god kultur for læring med bruk av digitale læringsformer hviler både på studenter og lærere. Det er derfor viktig å lytte til studentenes erfaringer og opplevelser for å kunne engasjere de som medspillere i kvalitetsutvikling av undervisning med teknologi (s. 321).

Vi har argumentert for at både studenter og fagpersoner trenger å bli mer bevisste på betydningen av individuelle fortolkninger, og hvordan disse rammes inn av kontekstuelle prosedyrer og rammer (Selwyn, 2009). Man kan på den ene siden hevde at studentene må sette seg inn i høgskolens tekniske løsninger, læringsplattform og akademiske databaser. På den andre siden må lærestedene og nye læringsteknologier ta hensyn til de erfaringene, kompetansene og forventningene som studentene har til mediebruk. Om spenningsforholdet mellom tilgang til digitale ressurser, forventningene blant studenter og faglærere, og de reelle digitale praksisene blir for stort, kan det føre til at fagpersonene ikke lenger ser seg tjent med å utvikle spenstige digitale læringsformer (Krumsvik, 2016, s. 322).

Styrken ved denne studien er at den bidrar med empiri på hvordan subjektive opplevelser av teknologi får betydning for hvordan studentene forholder seg til teknologi i undervisning og studiearbeid. Studiens begrensninger er at den omfatter relativt få deltakere, noe som gjør det utfordrende å identifisere store variasjoner i fortolkninger. Det kan derfor virke som studentgruppen hadde forholdsvis homogene fortolkninger og perspektiver. Det kan være nyttig å følge opp studien og da sammenligne på tvers av kjønn, sosial og kulturell bakgrunn, studieemner og studieerfaring/år. Selv om dette er en nærstudie, så supplerer og utvider den funn i tilsvarende studier. Vi ser imidlertid at det trengs mer forskning på hvordan fortolkningsrammer kan ha betydning for engasjement og deltakelse i læringsaktiviteter som involverer teknologi. 


\section{Referanseliste}

Adalberon, E. \& Säljö, R. (2015). Informal use of social media in higher education. A case study of Facebook groups. Nordic journal of digital literacy, 12(4), 114-128. doi: 10.18261/ISSN.1891-943X-2017-04-02

Adams Becker, S., Cummins, M., Davis, A., Freeman, A., Hall Giesinger, C. \& Ananthanarayanan, V. (2017). NMC Horizon Report: 2017 Higher Education Edition. Austin, Texas: The New Media Consortium.

Bjørgen, A. M. \& Erstad, O. (2014). The connected child: tracing digital literacy from school to leisure. Pedagogies: An International Journal, 1O(2), 113-127, doi: 10.1080/1554480X.2014.977290

Bolter, J.D. \& Grusin, R. (2001). Remediation: understanding new media. Cambridge, Mass: MIT Press.

Boyd, D. (2007). Why youth social network sites: The role of networked publics in teenage social life. D. Buckingham (Ed.), Youth, identity, and digital media (s. 119-142). Cambridge, MA: The MIT Press.

Brox, H. (2017). What's in a wiki? Issues of agency in light of student teachers' encounters with wiki technology. Nordic Journal of Digital Literacy, 2(4) 129-142. DOI: 10.18261/ISSN.1891-943X-2017-04-03

Buckingham, D. (2006). Is there a digital generation? D. Buckingham (Ed.), Digital generations: Children, young people, and new media (pp. 1-14). Mahwah, N.J.: Lawrence Erlbaum.

Burnett, C. (2015). Investigating children's interactions around digital texts in classrooms: how are these framed and what counts?. Education, 3-13, 43(2), 197-208. doi: 10.1080/03004279.2013.800576

Drange, E-M.D. \& Birkeland, R. (2016). E. S. Tønnessen, N.R. Birkeland, E-M.D. Drange, G. Kvåle, G-R. Rambø, \& M. Vollan (red.). Hva gjør lærerstudenter når de studerer? Lesing, skriving og multimodale tekster $i$ norsk grunnskolelærerutdanning. (s. 53-70). Oslo: Universitetsforlaget.

Fossland, T. (2015). Digitale læringsformer i høyere utdanning. Universitetsforlaget. ISBN 9788215023632.

Fritze, Y. (2005). Mediet gør en forskel. En komparativ undersøgelse af kommunikation i nærundervisning og fjernundervisning. [Doktorgradsavhandling]. Syddansk Universitet, Odense.

Fritze, Y., Haugsbakk, G. \& Nordkvelle Y.T. (2017). Digitale forstyrrelser i skolen - erfaringer med begrensninger av elevers mobilbruk. Norsk pedagogisk tidsskrift, 101(3), 201-212.

Goffman, E. (1986). Frame analysis: An essay on the organization of experience. Boston: Northeastern University Press.

Gourlay, L. (2014). Creating Time: Students, Technologies and Temporal Practices in Higher Education. Elearning \& Digital Media, 11(2), 141-153.

Haugsbakk, G. (2010) Digital skole på sviktende grunn - om nye muligheter og dilemmaer. Oslo: Gyldendal Akademisk.

Haugsbakk, G., \& Nordkvelle, Y. (2013). Den motvillige teknologen og læringssamfunnet. P. Arbo, T. Bull \& $\AA$. Danielsen (red.), Utdanningssamfunnet og livslang læring. Festskrift til Gunnar Grepperud (s. 113-138). Oslo: Gyldendal Akademisk.

Hui, D. (2018). Learning from New Literacies. The Changing Face of College English Among English Major ELL Learners. Nordic journal of digital literacy, 13(2) 71-93. doi: 10.18261/ISSN.1891-943X-2018-02-02

Ito, M., Baumer, S., Bittanti, M., boyd, d., Cody, R., Herr-Stephenson, B., Horst, H., Lange, P.G. Mahendran, D., Martínez, K.Z., Pascoe, C. J., Perkel, D., Robinson, L., Sims, C. Tripp. L. (2010). Hanging out, messing around, and geeking out: Kids living and learning with new media. Cambridge, Mass.: The MIT Press.

Johannessen, M., Øgrim, L., \& Giæver, T. (2014). Notion in motion: Teacher's digital competence. Nordic Journal of Digital Literacy, 9(4), 300-312.

Kvale S, Brinkmann S, Anderssen TM, Rygge J. (2015). Det kvalitative forskningsintervju. 3. utg., 2. oppl. ed. Oslo: Gyldendal akademisk.

Krumsvik, R. J. (2016). Digitale paradoks og undervisningskvalitet: epilog. R. J. Krumsvik (red.) Digital læring $i$ skole og lærerutdanning. Oslo: Universitetsforlaget.

Lankshear, C., \& Knobel, M. (2006). New literacies: Everyday practices and classroom learning. Maidenhead: Open University Press.

Lantz-Andersson, A. (2016). Embracing social media for educational linguistic activities. Nordic journal of digital literacy, 11(1) 50-77. doi: 10.18261/issn.1891-943x- 2016-01-03

Luhmann, N. (2000). Sociale systemer - grundrids til en almen teori. København: Hans Reitzels forlag.

Luhmann, N. (2006). Samfundets uddannelsessystem. København: Hans Reitzels forlag.

Moll, R, Nielsen, W. \& Linder, C. (2015). Physics students' social media learning behaviours and connectedness. International Journal of Digital Literacy and Digital Competence, 6(2), s. 16-35. doi: 10.4018/IJDLDC.2015040102

Postholm. M.B. (2005). Kvalitativ metode: en innføring med fokus på fenomenologi, etnografi og kasusstudier. Oslo: Universitetsforlaget.

Rasmussen, T. (2003): Luhmann. Kommunikasjon, medier, samfunn. Bergen: Fagbokforlaget. 
Säljö, R. (2010). Digital tools and challenges to institutional traditions of learning: Technologies, social memory and the performative nature of learning. Journal of Computer Assisted Learning, 26(1), 53-64. doi: 10.1111/j.1365-2729.2009.00341.x

Selwyn, N. (2009) Faceworking: exploring students' education-related use of Facebook. Learning, Media and Technology, 34(2), 157-174. doi: 10.1080/17439880902923622

Selwyn, N. (2016). Digital downsides: exploring university students' negative engagements with digital technology. Teaching in Higher Education, 21(8), 1006-1021. doi: 10.1080/13562517.2016.1213229

Tjora, A.H. (2017). Kvalitative forskningsmetoder i praksis. Oslo: Gyldendal Akademisk.

Tømte, C.E. \& Olsen, D.S. (2013). IKT og læring i høyere utdanning: kvalitativ undersøkelse om hvordan IKT påvirker i høyere utdanning. Oslo: Nifu.

Tønnessen, E.S., (2016). Oppsummering, drøfting og nye utfordringer. E.S. Tønnessen, N.R. Birkeland, E-M. D. Drange, G. Kvåle, G-R. Rambø, \& M. Vollan (2016). Hva gjør lærerstudenter når de studerer? Lesing, skriving og multimodale tekster i norsk grunnskolelærerutdanning. Oslo: Universitetsforlaget, s. 240-252.

Wertsch, J. V. (1998). Mind as action. New York: Oxford University Press.

Ørnes, H., Gaard, H., Refsnes, S.I., Kristiansen, T. og Wilhelmsen, J. (2015). Digital tilstand i høyere utdanning 2014. Norgesuniversitetets IKT-monitor. Norgesuniversitetets skriftserie 1/2011. Tromsø: Norgesuniversitetet.

\section{Forfattere}

\section{Anne Mette Bjørgen}

Førsteamanuensis

Institutt for pedagogikk, Fakultet for lærerutdannning og pedagogikk, Høgskolen i Innlandet

\section{Yvonne Fritze}

Førsteamanuensis

Institutt for pedagogikk, Fakultet for lærerutdannning og pedagogikk, Høgskolen i Innlandet

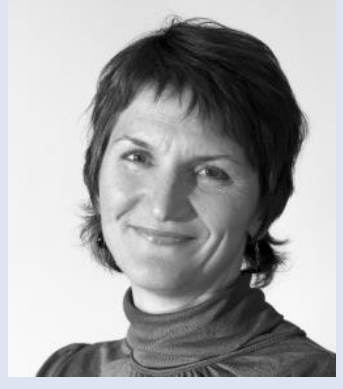

